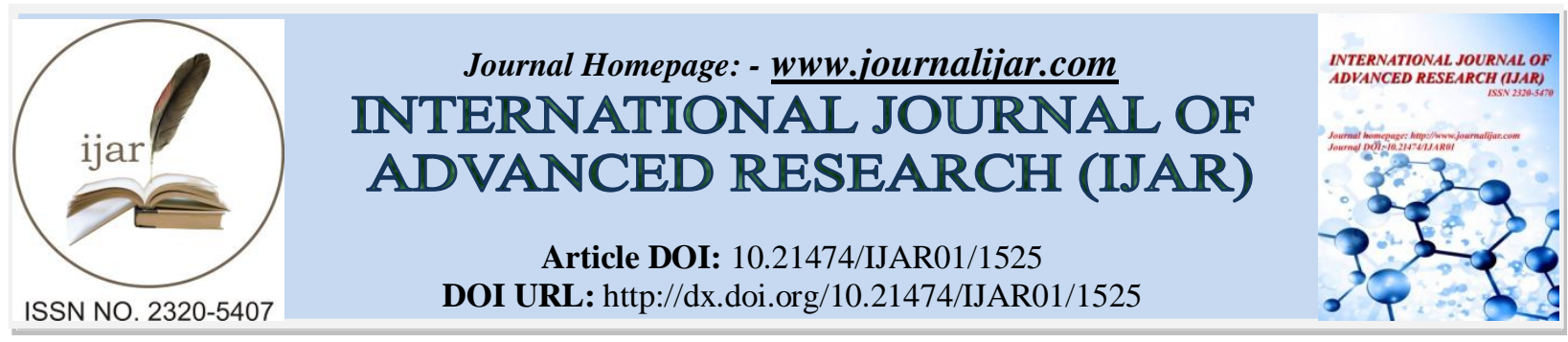

RESEARCH ARTICLE

\title{
THE IMPLICATIONS OF JOB SATISFACTION ON FIRM PERFORMANCE " (FILED STUDY: COMMERCIAL BANKS IN AMMAN)".
}

The World Islamic Sciences and Education University.

Safa khaled sarairah.

\section{Manuscript Info}

Manuscript History

Received: 12 July 2016

Final Accepted: 19 August 2016

Published: September 2016

Key words:-

Job Satisfaction, firm, Working

Condition,Pay and Promotion,Job

Security,Fairness.

\section{Abstract}

Aim:- find the effect of Job Satisfaction factors on firm performance at Commercial Banks in Amman.

Factors: independent factors:Job Satisfaction (Working Condition,Pay and Promotion,Job Security,Fairness) and dependent factor (firm perfroamce)

Method and Sampling:- The sample was Commercial Banks in Amman, 250 questioners distributed for employees worked in the field of study in Amman .236 were valid and analyzed

Finding:- there is an impact of each ofJob Satisfaction factors on firm performance at Commercial Banks in Amman like;Working Condition,Pay and Promotion,Job Security,Fairness and the most effect factor was pay and promotion.

Future work:- Determine the relation between the job satisfaction and job performance and their effect on organization performance.

Copy Right, IJAR, 2016,. All rights reserved.

\section{Introduction:-}

Job satisfaction is an indicator of how well a person is doing his or her job. Human resource management is a important aspects of an organization. Success and failure of an organization depends mostly on the performance of employees. Job satisfaction is obviously an important factor for all organizations. Companies must continuously improve employee satisfaction in order to stay profitable. Job satisfaction can be defined as an individual's general attitude toward his or her job [1].

One of the predominant areas of study in social sciences has been job satisfaction. Many studies varied in defining the term job satisfaction. Job satisfaction results from job appreciation or job achievement values and termed as a "pleasurable emotion" [2]. One's well being as mental and physical fitness is likely to result from his/her satisfaction at work. Several researchers explained two factors playing important role in the context of job satisfaction. First are individual's perceived work characteristics (rewards) and second is a work value which means the importance an individual associates with perceived work characteristics [3].

Therefore this research is attempted to study the effect of Job Satisfaction factors on firm performance at Commercial Banks in Amman.

\section{Literature review:-}

Spector (1997) [4]refers to job satisfaction in terms of how people feel about their jobs and different aspects of their jobs. Abraham Maslow(1954) [5] suggested that human needa from a five-level hierarchy ranging from 
physiological needs, safety, belongingess and love, esteem to self-actualization. Based on Maslow's theory, job satisfaction has been approached by some researchers from the perspective of need fulfillment.

The term job satisfaction. Job satisfaction results from job appreciation or job achievement values and termed as a "pleasurable emotion [6]. One's well being as mental and physical fitness is likely to result from his/her satisfaction at work. Several researchers explained two factors playing important role in the context of job satisfaction. First is individual's perceived work characteristics (rewards) and second is work values which means the importance an individual associates with perceived work characteristics [7]

Spector (1997) refers to job satisfaction in terms of how people feel about their jobs and different aspects of their jobs. Ellickson and Logsdon (2002) support this view by defining job satisfaction as the extent to which employees like their work. Schermerhorn (1993) defines job satisfaction as an affective or emotional response towards various aspects of an employee's work.

Job satisfaction and dissatisfaction not only depends on the nature of the job, it also depend on the expectation what's the job supply to an employee [8]. Lower convenience costs, higher organizational and social and intrinsic reward will increase job satisfaction [9] Job satisfaction is complex phenomenon with multi facets [10] it is influenced by the factors like salary, working environment, autonomy, communication, and organizational commitment [11]

Job satisfaction and firm performance are great interest to both academics and practitioners. On the other hand, it is important for how managers approach employee recruitment, retention, and motivation, and more generally the importance of human resource management .A satisfying workplace can foster job embeddedness and ensure that talented employees stay with the firm. job satisfaction can provide a valuable recruitment tool, job satisfaction can improve worker motivation, also Job satisfaction can promote organizational citizenship behaviorwhere an employee goes above and beyond the formal requirements of the job, internalizing the Örmís objective function as his/her own [12]

\section{Study Hypotheses and Model:-}

The study hypotheses have therefore been developed as:

1. There is no significant statistical effect of working conditionon firm performance at level of $(\alpha \leq 0.05)$

2. There is no significant statistical effect of pay and promotion on firm performance at level of $(\alpha \leq 0.05)$

3. There is no significant statistical effect of job securityon firm performance on firm performance at level of $(\alpha \leq 0.05)$

4. There is no significant statistical effect of fairnesson firm performance at level of $(\alpha \leq 0.05)$

Figure 1 shows the study model, with the four variables proposed to affect quality of service in e- government systems(e- participation, m-government, and opendata)

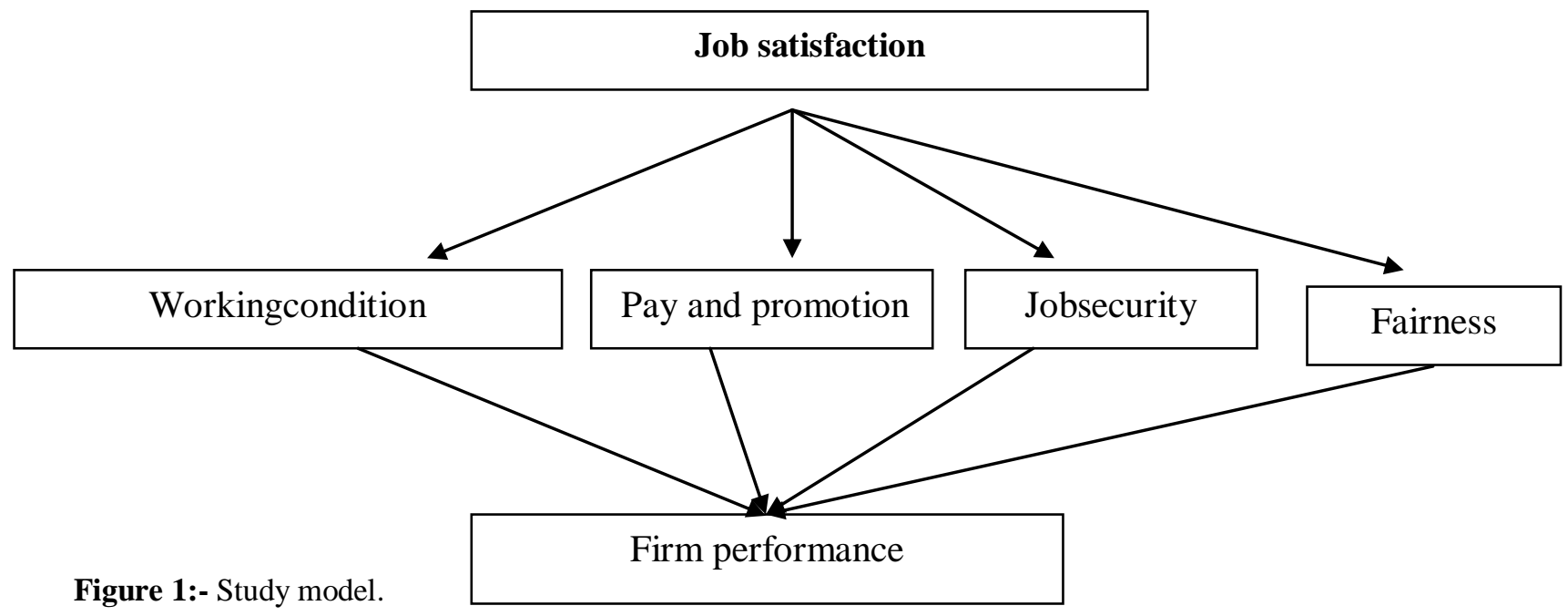




\section{Materials and Methods:-}

Study Population and Sample:-

The population of the study consisted of employees from all levels of managerial in commercial banks in Amman .The sample chosen for this study represent a large number of the population., a total of 250questioners have been disrupted, 236 back and was valid to analyze.

\section{Study Tools and Data Collection:-}

Since there have been no previous studies on the field of study, there was no suitable survey instrument. We therefore developed our own, based on the factors emerging from the literature. This survey was designed to explore the perceptions of employee about their Job satisfaction and its effect on firm performance, using Likert-type scales

A total of 20 questions in an initial survey were piloted in the field of study out of the full sample. The piloting aimed to identify any questions where answers were not equally distributed, or which were consistently not completed by respondents, and any other aspects which could reduce the response rate. The responses were assessed for validity and reliability.

\section{Data Analysis:-}

Percentage, frequency, mean and standard deviation were used to describe the sample and basic responses. Simple linear regression analysis with (F) test was used. SPSS (v20) was used to analyze all the data. Relative importance of individual factors was assigned using: Class interval $=$ (maximum class - minimum class $) /$ number of levels $=$ $(5 i 1) / 3=4 / 3=1.33$ A low degree of importance was less than 2.33, median was 2.33-3.66 and high was 3.67 and above.

\section{Results and Discussion:- \\ Survey Development:-}

There were no missing data from the pilot study, suggesting that the respondents found all the questions comprehensible. The responses from the pilot study were grouped into factors. Although the pilot sample size was small, the results suggest that the variables within each factor showed a correlation of over $60 \%$. Cronbach's alpha for the overall pilot study was 0.94 ,showing good reliability. No evidence of multi-co linearity was found in the pilot study.

Table 1:- Cronbach's alpha $(\alpha)$ to test reliability.

\begin{tabular}{|l|l|}
\hline Variables' & Cronbach's alpha \\
\hline Working conditions & .92 \\
\hline Pay and promotion & .95 \\
\hline Job security & .91 \\
\hline Fairness & .90 \\
\hline Over all 0.92 & .95 \\
\hline Firm performance & $\mathbf{. 9 4}$ \\
\hline Over all &
\end{tabular}

\section{Hypothesis testing:-}

Table 2:- F-Test for hypothesis.

\begin{tabular}{|l|l|l|}
\hline Variables' & T- test & Result \\
\hline $\mathrm{H}_{0} 1:$ working conditions , firm performance & 2.265 & Refused \\
\hline $\mathrm{H}_{0} 2:$ pay and promotion , firm performance & 2.218 & Refused \\
\hline $\mathrm{H}_{0}$ : job security, firm performance & 2.454 & Refused \\
\hline $\mathrm{H}_{0} 4$ : fairness , firm performance & 2.012 & Refused \\
\hline
\end{tabular}

By looking at table (2) we can see that the absolute value of $\mathrm{F}$ calculated in every factor more than $\mathrm{F}$ tabulated at level $(\alpha \leq 0.05)$. This indicates that all hypotheses are valid. Therefore, the null sub-hypotheses were refused and the alternative accepted 


\section{Conclusion and Recommendations:-}

1. There is significant statistical effect of working conditions on firm performance in Amman Jordan banks

2. There is significant statistical effect of pay and promotion on firm performance in Amman Jordan banks

3. There is significant statistical effect of job security on firm performance in Amman Jordan banks

4. There is significant statistical effect of fairness on firm performance in Amman Jordan banks

Based on previous results and conclusions, the following recommendations might help in enhancing e government systems and its quality of service

1. Investigate the potential relationships and affects these variables and other extraneous variables, such as role ambiguity, job level, contingent rewards and co-work have on job satisfaction.

2. Create favorable work conditions for the company. Guide the employee to communicate effectively, build a good interpersonal environment within the company, in order to create good work conditions.

3. Improve fairness in banks; create a scientific bank appraisal system in the organization. Utilize the other developed countries' scientific performance systems, and use these systems to evaluate employee work performance and evaluate employee service quality.

4. Recognize the efforts of employees and appreciate their valuable performance towards organization.

5. Improve the Policy of Training Promotion.

\section{References:-}

1. Robbins, S.P.; Odendaal, A. and Roodt, G. Organisational Behaviour, Global and Southern African Perspectives. (Cape Town, Pearson Education, 2003).

2. Lock E.1969 "what is job Satisfaction?" Organizational Behavior and human performance 4: 309-366.

3. Hui M.K, Kevin Au, Fock H, 2004, "Empowerment Effects across Cultures", Journal of International Business Studies, Vol. 35, pp. 46-60.

4. Spector, P. E. (2000). Industrial \& organizational psychology (2nd ed.). New York: John Wiley \& Sons.

5. A.H. Maslow (1954) Motivation and Personality. New York: Harper \& Row.

6. Lock E.1969 "what is job Satisfaction?" Organizational Behavior and human performance 4: 309-366.

7. Hui M.K, Kevin Au, Fock H, 2004, "Empowerment Effects across Cultures", Journal of International Business Studies, Vol. 35, pp. 46-60.

8. AL-Hussami M (2008). A Study of nurses' job satisfaction: The relationship to organizational commitment, perceived organizational support, transactional leadership, transformational leadership, and level of education. Eur. J. Sci. Res., 22(2): 286-295.

9. Mulinge M, Muller CW (1998). Employee Job Satisfaction in Developing Countries: The Case of Kenya. World Dev., 26(12): 2181-2199.

10. E. A Locke (1980)The Nature and Causes of Job Satisfaction. M.D Dunnette (Ed.), Handbook of Industrial and Organizational Psychology, Chicago, Rand McNally. pp.1297-1349

11. Vidal MES, Valle RS, Aragón BMI (2007). Antecedents of repatriates' job satisfaction and its influence on turnover intentions: Evidence from Spanish repatriated managers. J. Bus. Res., 60: 1272-1281.

12. Edmans, Alex(2012).The Link Between Job Satisfaction and Firm Value, with Implications for Corporate Social Responsibility,London Business School - Institute of Finance and Accounting; European Corporate Governance Institute (ECGI); Centre for Economic Policy Research (CEPR). 